\title{
SUPPLY ANALYSIS OF WINDY SEKUMPUL PEMPEK MARTAPURA BEFORE AND DURING THE COVID-19 PANDEMIC
}

\author{
Norfirdaus Anas*, Mahreda Emmy Sri, Lilimantik Emmy, Ahmadi \\ University of Lambung Mangkurat, Banjarbaru, Indonesia \\ *E-mail: anasnorfirdausspi12@gmail.com
}

\begin{abstract}
The Covid-19 pandemic has resulted in a global health crisis and has had a serious impact on the activities of food micro, small and medium enterprises (MSMEs) in Banjar Regency. Business actors stop production or switch business professions. This study aims to analyze the offer of Pempek Windy Sekumpul Martapura before and during the Covid-19 pandemic, initial survival strategies and future business development strategies. Pempek Windy Sekumpul Martapura is a small and medium micro business actor with pempek, a typical food of Palembang, South Sumatra Province, Indonesia which is made from sago flour, wheat flour and mashed Mackerel fish meat. Pempek is a favorite dish of Indonesian people. This study uses a qualitative approach. The research subject is Pempek Windy Sekumpul Martapura Village, Banjar Regency, South Kalimantan Province, Indonesia. While the object of research is the offer of Pempek Windy Sekumpul Martapura before the Covid-19 Pandemic (2019) and during the Covid-19 Pandemic (2020). The data were obtained from interviews, observations, documentation and supporting data from the Banjar Regency Industry and Trade Office and the Banjar Regency Central Statistics Agency. The data of the Pempek Windy Sekumpul offerings was carried out by the Wilcoxon Test with the help of the SPSS application. The initial defense strategy was carried out descriptive analysis and the Business Development Strategy was carried out SWOT analysis. The results showed that there was no significant difference to the Pempek Windy Offers as a group of Martapura before and during the Covid-19 pandemic. The initial strategy to survive is the very affordable price of pempek, a strategic location, maintaining the availability of production raw materials, prices, solid team work, strong owner character, diverse product marketing system, and customer relationship management to establish good relationships with customers. Strategy Development in the future is an aggressive strategy by expanding the business and diversifying products.
\end{abstract}

\section{KEY WORDS}

Pempek, COVID-19, enterprises, public service.

The World Health Organization has declared Corona Virus Disease 2019 (Covid-19) as a pandemic. Indonesia has also designated Covid-19 as an outbreak or pandemic on April 13,2020 . Corona virus or SARS-CoV-2 is a virus that attacks the respiratory system with the most common symptoms being fever, dry cough, and fatigue. The disease caused by SARSCoV-2 is referred to as Covid-19. Covid-19 causes severe infections in the lungs that are severe enough to cause death. This virus is contagious very quickly and has spread to almost all countries. Various countries have implemented lockdown policies to reduce the impact of the spread of Covid-19.

In addition to creating a global health crisis, the Covid-19 pandemic has also caused negative sentiment on economic growth in Banjar Regency. Sectors related to the Pempek Windy Sekumpul business are fisheries, manufacturing, wholesale and retail trade, and the provision of accommodation and food and drink, which experienced negative growth, the values were $-2 \%,-2.87 \%,-3.93 \%$ and $-0.44 \%$. Likewise, the Gross Regional Domestic Product (GRDP) of Banjar Regency penetrated the negative number, namely $-1.96 \%$ (Riva'i, 2021).

The Covid-19 pandemic had an impact on the Small Food Industry in Banjar Regency in 2020 compared to 2019 with a decrease in business unit growth $-5.15 \%$, employment - 
$6.58 \%$, production value $-18.06 \%$ and raw material value $-13,91 \%$ while the investment value increased by $12.21 \%$ (Banjar Industry and Trade Office, 2021)

The pandemic crisis has an impact on the Micro, Small and Medium Enterprises (MSME) Sector compared to large businesses. This is different from the 1998 crisis, MSMEs were more persistent. The pandemic has had two of the worst impacts on MSMEs, namely in terms of demand and supply of goods/services according to the Organization for Economic Co-operation and Development (OECD). This can be seen from the supply side, business actors face production constraints in the form of processes that are disrupted by regional quarantine (lockdown), restrictions on community activities, and workers who cannot maximize their potential due to illness, mandatory self-quarantine, and others. On the other hand, from the demand side, there was a dramatic change that put pressure on their income, thus disrupting the liquidity of these business actors.

Banjar Regency has a large potential for processing fishery products with a wide variety of products such as kerupuk ikan (fish crackers), abon ikan (shredded fish), amplang, fish sticks, salted fish, fish rengginang, frozen food (meatballs, pempek). In this unfavorable situation. the processing groups stopped their production, and some processing groups reduced their production by up to $80 \%$. This is due to the difficulty of raw materials as a result of regional partitions that hinder the distribution of goods and the mobility of people. The decline in people's purchasing power triggered by Termination of Employment (PHK) resulted in decreased demand for processed products (Banjar Fisheries Extension Interview, 2021). The Central Statistics Agency for Banjar Regency in 2021 recorded an unemployment rate during the Covid-19 pandemic of 12,317 people.

Pempek Windy Sekumpul Martapura is one of these processing groups. This pempek business was founded in 2009, starting with selling pempek with wheelbarrows, within 6 months it was possible to rent a house and shop in the Sekumpul Urban Village area. The building is separated into two parts (for the production room and the restaurant). Mrs.Wiwik Kesumawati as the owner with all the calculations for renting a shophouse, she is very sure that the pempek request will have good prospects. The variant of pempek is a submarine filled with chicken eggs, a submarine filled with duck eggs, lenjer, skin, adaan, shrimp and small eggs. With 6 employees and assisted by 2 people, the business continues to grow and open a new branch at the Culinary Market, Pasar Martapura. As an MSME based on processed food from mackerel, it has advantages, including providing food needs to survive, maintain health and increase body immunity.

The offer of Pempek Windy Sekumpul during the Covid-19 Pandemic was 547,579 pieces, an increase from the previous period of 527,705 pieces or $3.76 \%$. This increase in supply is in contrast to most other business actors who stop production, reduce production or switch other businesses. In other words, Pempek Windy Sekumpul has successfully survived the Covid-19 pandemic. Therefore, it is necessary to analyze the offer of Pempek Windy Sekumpul along with strategies for survival and future business development.

\section{METHODS OF RESEARCH}

This research was conducted at the business location of Pempek Windy Sekumpul Martapura which is located on Jl. Sekumpul Raya RT 003 RW 002 Sekumpul Martapura Village, Banjar Regency, South Kalimantan Province, to obtain data or information about pempek offers before and during the covid-19 pandemic. This research is a comparative causal research. Data or information is obtained after the occurrence of a situation, event or fact (ex post facto). The situation or fact in question is the Covid-19 Pandemic. The research was conducted by comparing the offers of pempek in 2019-2020. The Covid-19 pandemic is still ongoing. So the research is limited to the period 2019-2020. The 2019 period describes the period before the Covid-19 pandemic and the 2020 period describes the period during the Covid-19 pandemic.

Data collection methods are very helpful for formulating research results. In this study, data were collected by means of documentation. This method was chosen because the data in this study were secondary data. The data and information that have been collected are 
processed and analyzed descriptively and quantitatively. Descriptive analysis is used to analyze the data by creating tables, grouping the data, then describing it. Descriptive analysis is carried out to describe the initial strategy to survive the COVID-19 pandemic situation, while to explain future business development strategies, a SWOT analysis is carried out. The quantitative analysis in this study was carried out by accumulating pempek offers in the 2019 and 2020 periods, and then analyzed using non-parametric statistics Wilcoxon test with the SPSS application. In order to find out whether there is a difference (significance) in Pempek's offers before and during the Covid-19 pandemic, the following hypothesis was made:

- H0: There is no difference in the offer of Pempek Windy Sekumpul before and during the Covid-19 Pandemic;

- $\mathrm{H} 1$ : There is a difference in the offer of Pempek Windy Sekumpul before and during the Covid-19 pandemic.

Study (Raharjo, 2014) explain statistical testing using SPSS: sig value $>0.05$, then $\mathrm{H} 0$ is accepted sig value $<0.05$, then $\mathrm{H} 0$ is rejected, so accept $\mathrm{H} 1$.

The selection of Pempek Windy Sekumpul as the research location was based on considerations of having complete business legal aspects, good management and bookkeeping and the most successful surviving the Covid-19 pandemic situation. So that it best describes the business situation during the COVID-19 pandemic.

\section{RESULTS AND DISCUSSION}

Based on the data offered by Pempek Windy Sekumpul, after the calculations are carried out, the data is processed and the following data are obtained:

Table 1 - Offers of Pempek Windy Gathered Before and During the Covid-19 Pandemic (Th 2019 \&2020)

\begin{tabular}{|c|c|c|c|c|c|c|c|c|c|c|c|c|c|c|}
\hline \multirow{3}{*}{ No } & \multirow{3}{*}{ Types of Pempek } & \multicolumn{13}{|c|}{ MONTH } \\
\hline & & \multicolumn{3}{|l|}{ Jan } & \multicolumn{2}{|l|}{ Feb } & \multicolumn{2}{|l|}{ Mar } & \multicolumn{2}{|l|}{ April } & \multicolumn{2}{|l|}{ May } & \multicolumn{2}{|l|}{ Jun } \\
\hline & & 2019 & \multicolumn{2}{|l|}{2020} & 2019 & 2020 & 2019 & 2020 & 2019 & 2020 & 2019 & 2020 & 2019 & 2020 \\
\hline 1 & $\begin{array}{l}\text { Kapal selam } \\
\text { With Duck egg }\end{array}$ & 149 & \multicolumn{2}{|l|}{197} & 172 & 140 & 113 & 187 & 155 & 203 & 156 & 188 & 103 & 259 \\
\hline 2 & Small Egg & 24,246 & \multicolumn{2}{|l|}{24,191} & 23,959 & 19,800 & 22.883 & 24,858 & 22,933 & 22,369 & 21.356 & 21,608 & 24,354 & 26.686 \\
\hline 3 & Shrimp & 13.633 & \multicolumn{2}{|l|}{18.024} & 12,054 & 12,571 & 12,546 & 13,049 & 13,319 & 11,764 & 11,714 & 11,646 & 12,948 & 15,361 \\
\hline 4 & $\begin{array}{l}\text { Kapal Selam } \\
\text { With Chicken } \\
\text { eggs }\end{array}$ & 1,792 & \multicolumn{2}{|l|}{1,499} & 1,449 & 1,115 & 1,491 & 1,412 & 1.513 & 1.361 & 1,340 & 1.544 & 1.568 & 1,634 \\
\hline 5 & Lenjer & 1.126 & \multicolumn{2}{|l|}{1,204} & 1.171 & 1.003 & 1.109 & 1,129 & 1.097 & 1.050 & 1.057 & 1,100 & 1,221 & 1,225 \\
\hline 6 & Kulit & 1,459 & 1,400 & & 1.513 & 1.316 & 1,471 & 1.553 & 1.348 & 1,746 & 1.033 & 1,614 & 1,482 & 2.085 \\
\hline 7 & adaan & 2.050 & 1,862 & & 1,922 & 1,866 & 2,152 & 2,203 & 2,416 & 1,639 & 1,832 & 1,711 & 2,345 & 1,966 \\
\hline & & & & & $\mathrm{MON}$ & & & & & & & Kum & & \\
\hline Jul & & August & & Sep & & Oct & & Nov & & Des & & Kum & & \\
\hline 2019 & 2020 & 2019 & 2020 & 2019 & 2020 & 2019 & 2020 & 2019 & 2020 & 2019 & 2020 & 2019 & & 2020 \\
\hline 136 & 231 & 137 & 239 & 132 & 233 & 149 & 240 & 254 & 257 & 258 & 196 & 1,914 & & 2,570 \\
\hline 23.867 & 28,258 & 23,398 & 27,072 & 23,126 & 25.088 & 23,499 & 25,126 & 27.504 & 30,663 & 27,693 & 26,298 & 288,818 & & 302,017 \\
\hline 13.848 & 15,488 & 12,120 & 15,655 & 12,741 & 13,130 & 13,365 & 12,756 & 14,905 & 14,015 & 15,172 & 14.549 & 158,365 & & 168.008 \\
\hline 1,631 & 1,594 & 1,419 & 1.513 & 1.515 & 1.358 & 1,772 & 1,471 & 1,720 & 1,501 & 1,872 & 1,438 & 19,082 & & 17,440 \\
\hline 1.163 & 1,221 & 1.105 & 1,446 & 1.038 & 1,140 & 1,167 & 1,267 & 1,224 & 920 & 1,430 & 1,138 & 13.908 & & 13,843 \\
\hline 1,559 & 2.033 & 2,771 & 1,844 & 1.311 & 2,612 & 895 & 2.063 & 1,613 & 2,080 & 1,872 & 2,161 & 18,327 & & 22.507 \\
\hline 2,249 & 1,655 & 2,223 & 1,880 & 2,324 & 1.546 & 2,274 & 1,647 & 2,423 & 1,731 & 3.081 & 1,488 & 27,291 & & 21,194 \\
\hline & & & & & & & & & & & & 527,705 & & 547,579 \\
\hline
\end{tabular}

Source: Secondary Data, 2021.
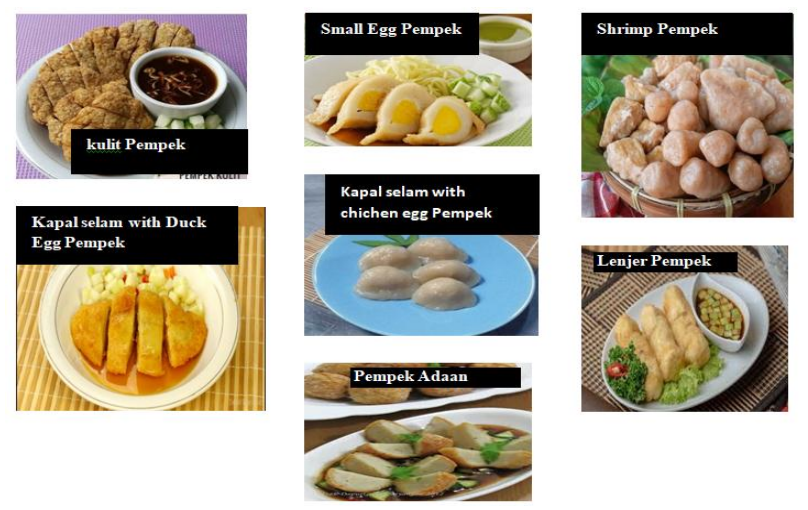

Figure 1 - Types of Pempek Windy Sekumpul 
Table 1 shows the offer of Pempek Windy Sekumpul before the Covid-19 Pandemic (2019) was 527,705 pieces consisting of: Kapal selam with Duck Egg 1,914 pieces, Small Eggs 288.818 pieces, Shrimp 158.365 pieces, Kapal selam with Chicken Egg 19,082 pieces, Lenjer 13,908 pieces, kulit 18,327 pieces, Adaan 27,291 pieces. While the offer Pempek Windy Sekumpul during the Covid-19 Pandemic (2020) is 547,579 consisting of: Kapal selam with Duck Egg 2,570 pieces, Small Eggs 302,017 pieces, Shrimp 168.008 pieces, Kapal selam with Chicken Egg 17,440 pieces, Lenjer 13,843 pieces, kulit 22,507 pieces, Adaan 21,194 pieces.

Pempek Windy Sekumpul Martapura offers 7 variants of pempek namely Kapal selam with Duck Egg, Kapal selam Chicken Egg, Lenjer, Shrimp, Small Egg, kulit and Adaan.

Table 2 - The Wilcoxon Statistical Test results

Ranks
\begin{tabular}{|l|l|l|l|}
\hline $\mathrm{n} / \mathrm{n}$ & $\mathrm{N}$ & Mean Rank & Sum of Rank \\
\hline During Covid-19 Negative Ranks & 3a & 3.00 & 9.00 \\
\hline Before Covid-19 Positive Ranks & $4 \mathrm{~b}$ & 4.75 & 19.00 \\
\hline Ties & $0 \mathrm{c}$ & & \\
\hline Total & 7 & & \\
\hline
\end{tabular}

Source: Data Analysis, 2021.

Note:

a. During Covid-19 < Before Covid-19;

b. During Covid-19 > Before Covid-19;

c. During Covid-19 = Before Covid-19.

The value of Negative Ranks $\mathrm{N}=3$ indicates there are 3 Variants of Pempek Windy Sekumpul which have decreased production compared to before the covid-19 pandemic, namely: Kapal selam with chicken egg pempek is 1642 pieces (8.6\%); Lenjer Pempek 65 $(0.5 \%)$ and Adaan pempek 6.097 (22.3\%). While Positive Ranks $N=4$ indicates that there are 4 variants of Pempek Windy Sekumpul which experienced an increase in production compared to before the Covid-19 pandemic, namely: Kapal selam with Duck Eggs 656 pieces (34.3\%); Small Eggs 13199 pieces (4.5\%); Shrimp 9643 pieces (6\%); and 4.180 skins $(22.8 \%)$. Meanwhile, Ties $\mathrm{N}=0$ indicates that there is no variant of Windy Sekumpul Pempek whose production is fixed.

Trimawartinah (2020) explained to find out whether there was a difference (significance) of the Pempek Windy Sekumpul Offers before and during the Covid-19 Pandemic against the Analysis of Sekumpul Windy Pempek Offers Before and During the Covid-19 Pandemic, the following hypothesis was carried out:

- H0: There is no difference in the offer of Pempek Windy Sekumpul Before and During the Covid-19 Pandemic;

- $\mathrm{H} 1$ : There is a difference in the offer of Pempek Windy Sekumpul before and during the Covid-19 pandemic.

Statistical Testing using SPSS:

- $\quad$ Sig value $>0.05$, then $\mathrm{HO}$ is accepted;

- Sig value $<0.05$, then $\mathrm{HO}$ is rejected, so accept $\mathrm{H} 1$.

Table 3 - Interpretation of SPSS Output Results

Test Statistics

\begin{tabular}{|l|l|}
\hline $\mathrm{n} / \mathrm{n}$ & During Covid-19 - Before Covid-19 \\
\hline $\mathrm{Z}$ & $-.845 \mathrm{~b}$ \\
\hline Asymp. Sig. (2-tailed) & .398
\end{tabular}

Source: Data Analysis, 2021.

Note:

- Wilcoxon Signed Ranks Test

- $\quad$ Based on negative ranks. 
Obtained Asymp Sig Value (2-tailed) of 0.398 , this value is greater than 0.05 , it means that there is no significant difference in the offerings of pempek windy collected before and during the Covid-19 pandemic. There is no Effect of the Covid-19 Pandemic on the Pempek Windy Sekumpul Offers.

According to Hanafie (2010) There are several things that contribute to the supply of goods from producers: product prices, number of producers, input prices, technology, expectations of goods in the future, and elasticity of goods.

The price of Pempek Windy Sekumpul is very affordable for customers. Prices are very varied starting from IDR 1000 for the Small Egg Pempek and Shrimp Pempek variants, the price is IDR 3000 for the kulit and Adaan Pempek, the price is IDR 11,000 for the Kapal selam with Chicken Egg Pempek and the price is IDR 15,000 for the Kapal selam with Duck Egg Pempek. Customers have the freedom to choose the desired pempek according to their tastes and financial conditions. With these variants and prices, the customer segmentation is very wide ranging from children, teenagers and adults. Such as pempek kulit, adaan, small eggs, shrimp are much liked by children and teenagers, while pempek kapal selam with duck eggs or chicken eggs and lenjer pempek are much liked by adults. Small eggs pempek and shrimp are selling very well because tastes and prices are in line with consumer expectations. The price of Pempek Windy assemblage is the most affordable among other pempek producers. Purchases with a package or mixed system may be burdensome for customers and are not free to choose what pempek to buy. Meanwhile, at Pempek Windy Sekumpul only IDR 5000 can enjoy at the restaurant comfortably. This may be what makes the strength and uniqueness of Pempek Windy come together so that it makes loyal customers.

Many producers initially make the supply increase, then there is competition between producers until finally the supply does not increase anymore. The number of producers can be a threat and can also have a positive influence on maintaining quality and increasing production and product competitiveness. Pempek Windy Sekumpul as stated by the owner, is not afraid of the many pempek producers. Competitive prices and flavors and a comfortable place to eat become a force to compete among fellow pempek producers. There are in the survey planning 2 places to develope their pempek business in addition to the existing branch in the Culinary Area, Martapura Market, Banjar Regency.

Prices of inputs or production factors will determine production costs and in the end become a reference for determining the price of pempek offered. Including production inputs are mackerel fish raw materials IDR 50,000 - 55,000 per kg in certain situations such as the fasting month or times of difficult catch. At that time, the price of mackerel fish could reach IDR 60,000 - IDR 75,000 per kilogram. The price of additional materials is IDR 300,000; labor wages: 6 people x Rp. 60,000 ; Electricity, Water, Wifi etc.: IDR 1.000 .000 ; Ruko rent IDR 40,000,000 per year. The raw materials for Mackerel fish are obtained from Batulicin Port, Trisakti Port Banjarmasin and Banjarbaru Market as well as savings and loans for raw materials between business actors in Banjarbaru. With these sources of raw materials, so far, the quality, availability and continuity of raw materials have been maintained. Additional ingredients include: Wheat flour, chilies, eggs, cooking oil, tamarind etc. were obtained from the Martapura Market, Banjar Regency. The price of additives often fluctuates but usually an increase in a commodity is followed by a decrease in other additives. So they cross subsidize each other so that the impact of the increase in materials is not too pronounced.

The labor wage of IDR 60,000/person is the net wage. As for eating and drinking, housing and other necessities have been borne by the owner. Employees can focus on work because all their needs have been met. Number of Employees Pempek Windy Sekumpul of 6 women assisted by 2 persons of the owner who handles administration and finances. Employee recruitment is carried out on the selection and recommendation of resigned employees. Employees who resign usually because of marriage. The recruitment method is intended to quickly integrate with other employees, quickly get the chemistry. Meanwhile, the assignment of the owner's son is not only to teach and train business skills but also to prepare good administrative and financial reports. This report is very important for business evaluation and determining future business strategy. 
Other fixed costs are electricity, water, credit and shophouse rental. Electricity is provided by PLN, water from PDAM is stored in tanks or tendons and cleaned regularly to maintain water quality. Phone credit is important for marketing media via social media, gojek and confirming requests for raw materials etc. The shop house occupied is still rented, IDR $40,000,000$ / year. Several times, Ruko wanted to be bought, because they felt it was suitable for the business there, but the owner was not sold or released. 2-storey shophouse building, the top floor is for employees to live on the bottom floor is divided into 2, for the purposes of the restaurant and the pempek production room.

Substitute goods also affect the supply of an item. If the price of substitute goods increases, the supply of these goods will increase, and vice versa. Meanwhile, if complementary goods increase, the supply of these goods will decrease, and vice versa. Substitute goods play an important role in the market. These goods are useful for consumers because they add many choices for consumers, what products are chosen to meet consumer needs. For producers, substitute goods are a threat. Lack of accuracy in determining prices results in consumers moving to substitute products, lowering sales, and lowering company profits.

Ahmad (2014) explain Complementary goods are goods whose use values complement each other.That is, if the item is used alone and there are no complementary items, then the need cannot be fulfilled perfectly. considering the importance of the role of complementary goods, this can cause other goods that have a functional relationship with them cannot be used optimally, or cannot be used at all. Complementary goods included in pempek are fish raw materials, cooking oil, wheat flour, etc. So far, an increase in the price of a complementary good is often followed by a decrease in the price of other complementary goods so that they can subsidize each other and maintain the price of the production input. Furthermore, the price of pempek remains stable and under control.

There are several goods that have the potential to become substitutes that cause consumers to switch, including meatballs, pentol kuah, martabak, siomay, and batagor. If the price of pempek increases, consumers will switch to these goods. In the last 3 years there has been no increase in the price of pempek, while the price of these goods is around IDR 10,000 - IDR 15,000 is still higher than the price of pempek which has its own customer segment. This is what keeps the Pempek Windy Sekumpul offerings stable and under control.

The utilization of Pempek Windy Sekumpul technology is more on digital technology such as e-payment, e-wallet, digital bookkeeping, and social media. Android-based electronic payments in collaboration with BRI Bank, BNI Bank, BI Bank, GoPay and OVO. Customers only need to confirm the transaction on android after scanning the Qris Code Pempek Windy Sekumpul.

The available E-Wallet is GoPay. Payment service facilities based on GO-JEK Online Ojek, provide convenience in non-cash transactions. There are 2 types of gopay accounts, namely a maximum balance of 2 million and a maximum balance of 10 million. Another advantage is being able to make payments for credit and data, pay bills such as Health Social Security Agency, electricity budget, internet budget, credit installments, indihome, PDAM (State Water Enterprise), pay TV, online shop payments or offline stores. Frequent promos and discounts of up to $50 \%$ and being able to transfer gopay balances to other friends completes the benefits of this service.

OVO, the best e-wallet in Indonesia is an online payment system based on a mobile application that makes payments simple without cash. OVO providers include: Beauty, fashion, F\&B, travel, transportation and exclusive partnerships with big brands. The convenience obtained with OVO is to go anywhere without cash, transactions can still be done without waiting for change; collect and pay with OVO points (1 OVO point $=R p 1)$; attractive promos and offers: OVO Primer allows Peer to Peer \& Bank Transfer; top up via ATM, m-Banking, internet banking and debit cards or through selected merchants; can make payments for electricity, telephone, internet or insurance bills; charitable donations for brothers in need; make investments. 
Bookkeeping at Pempek Windy Sekumpul is done digitally with the LAMIKRO, BUKU WARUNG and $99 \%$ USAHAKU applications, the results of workshops organized by Bank BI, the Ministry of Cooperatives and SMEs, and Telkomsel. LAMIKRO, Micro Business Accounting Report, is a simple, flexible accounting bookkeeping application with many userbased options for micro-enterprises via Android-based smartphones. Multiple procedures in budgeting and powerful enough to perfect the old method of manual recording. The features available are journal entries, journal lists, profit and loss and balance sheets.

Warung Buku is a remittance and accounting application model for business activities. The advantage is that it saves time because it can send money and account records via mobile devices from anywhere and anytime; simple and secure money transfer; has a history of transactions, helps to calculate and track money sent to recipients.

The 99\% Usahaku application from Telkomsel completes a variety of business solutions for Small and Medium Enterprises. In Era 4.0, Pempek Windy Sekumpul is required to go digital. 99\% Usahaku is an application-based service platform for Micro, Small and Medium Enterprises business actors, with various learning content including digital learning, business information articles, success stories of Micro Small Business actors, communication forum features between micro and small business actors, various micro small business service solutions. from Telkomsel Enterprise, as well as access to a wider market coverage in order to increase the sales capacity of its products.

Pempek Windy Sekumpul realizes the importance of understanding the presence of technology to improve efficiency, productivity and business competitiveness. Through a variety of digital-based business solution services accompanied by rapid adoption of these technologies, it will strengthen the digital economy ecosystem in business activities (Kenneth C. Laudon, 2008).

This payment method is used by customers, both middle and lower, has provided convenience and has the effect of repeat visits or re-transactions.

Expectations of goods are felt at certain times, moments and events such as official government events, Eid, weddings, circumcisions, birthdays, campus events, exhibitions, and cheap markets. At that moment there was a surge in the supply of pempek so that raw materials, auxiliary materials, labor and time were needed. In the end, taking advantage of this moment will increase Pempek Windy Sekumpul's income.

The elasticity of supply is the sensitivity of the quantity supplied of a good to the price of the good itself. The elasticity of supply measures the percentage change in quantity supplied due to a percentage change in price. In the last 3 years, the price of Pempek Windy Sekumpul has been relatively stable; there has been no price increase so that there is perfect elasticity, where prices remain followed by additional supply.

Strategy for survival during the Covid-19 Pandemic:

- Very Affordable Pempek Prices. The highest price for Pempek Kapal Selam with Duck Egg) is IDR 15,000; Kapal selam with Chicken Egg IDR 11,000; Pempek Lenjer IDR 10,000; Pempek Lenjer or Adaan each of IDR 3,000; Shrimp Pempek or Small Egg Pempek IDR 1,000. Customers have the freedom to choose pempek according to their taste and budget, this is rarely found in other manufacturers. Other manufacturers generally sell their pempek with a package or mix system;

- Strategic Place. The business location of Pempek Windy Sekumpul is a commercial and dense residential area where there are markets, shop houses, offices, housing, hospitals and religious tourism in the form of the Abah Guru Sekumpul Dome. This causes the Sekumpul area to become the lifeblood of the economy and is very appropriate for business activities, especially Pempek in Banjar Regency;

- Maintaining the Availability of Production Raw Materials. Aspects of the availability of raw materials related to quality, quantity and continuity are always maintained and considered. In the season where there is a lot of fish catch, the owner keeps the raw materials in the freezer. To anticipate the difficult seasons to get raw materials. Sometimes the price doesn't matter as long as there are goods and quality. To maintain the availability of raw materials for production, there are three sources of raw materials, namely Batu Licin Port, Tri Sakti Port and Banjarbaru Market. In 
addition, at certain times there are savings and loans of raw materials. Owners borrow raw materials from other groups. When the raw materials have been obtained, the borrowed raw materials are returned. With this source of raw materials, so far there have been no significant problems with the availability of raw materials;

- Solid team work. There are 6 employees who work at Pempek Windy Sekumpul outside the owner's 2 persons, all women and the same age. They are not married and are in their productive age of $15-20$ years. The division of tasks was carried out; preparation of production (both at the main location in Sekumpul and in the Martapura Culinary Mart), the activities include cleaning and sweeping the floor, preparing pempek serving facilities, tidying and cleaning tables and chairs, preparing meals for employees The second activity is pempek production. Its activities are in the form of weeding, milling, kneading, stamping and boiling; These activities were carried out alternately, the team that had carried out production preparation activities the next day carried out pempek production activities. The owner and the owner's children are actively involved in these activities, so that it is not visible between the leadership and subordinates, united into a solid team work. Owners call their employees "nak" while employees call their owners "mama". A call that is very familiar and seems very protective. What is felt is that the relationship between children and parents is not superior and subordinate. The team complements each other and helps when there is a problem. Because the problems that occur become common problems that can be overcome and resolved together. There is no envy and calculation in work. What is felt is that the relationship between children and parents is not superior and subordinate. The team complements each other and helps when there is a problem. Because the problems that occur become common problems that can be overcome and resolved together. There is no envy and calculation in work. What is felt is that the relationship between children and parents is not superior and subordinate. The team complements each other and helps when there is a problem. Because the problems that occur become common problems that can be overcome and resolved together. There is no envy and calculation in work.

The owner is from Palembang, Pempek is the best-known of Palembang's dishes. Its origin is undoubtedly Palembang. The owner started the pempek business in 2009 with a wheelbarrow in front of the Pelita Insani Martapura Hospital. It only takes 6 months; dare to rent a shophouse in Sekumpul Village with a cost rent IDR 40,000,000/year. The decision to rent a shophouse was taken based on the consideration that the community's demand for pempek production was very good. Customers also want to enjoy pempek comfortably in a restaurant. Pempek that is wrapped and eaten on the spot is certainly very different in taste. The owner has a great sense of responsibility towards her subordinates. All the necessities of life are met such as salary, food, housing. If sick is treated, until hospitalization in the hospital if necessary. Listen to subordinates vent about life problems and provide solutions. While printing, kneading and boiling pempek, they often confide in their life problems. One time she was in debt because she was cheated by a partner. Although the finances are not sufficient, with difficulty repaying the debt until it is paid off. Sociable, friendly and easy to get along with, various trainings, workshops from the Regency, Province, Ministry or other business institutions are always followed. Likewise, exhibitions and competitions for fishbased preparations are never to be missed. All of them also add to the competencies and networking that are needed in the business development of Pempek Windy Sekumpul.The key to success in surviving difficult and unfavorable situations is adaptation and innovation. Inspiring, being an inspiration for employees and her children.

There are several marketing systems at Pempek Windy Sekumpul:

- Restaurant, customers enjoy pempek in a very representative place. The room is spacious and comfortable, lots of tables and chairs are available, there is air conditioning and music is open from $11.00-21.00$ every day. The restaurant is not only in Sekumpul Village but also in the branch, Martapura Culinary Mart.

- Resellers, someone buys for resale with the intention of making a profit from the sale. The pempek is promoted and then resold at a higher price than the initial price purchased 
by the reseller. A reseller more or less requires capital to stock up on goods to be resold in addition to expertise and networks or connections to market the pempek. There are 6 resellers currently, for the Martapura, Banjarbaru, Banjarmasin and Hulu Sungai areas.

- Go-Food an online delivery service on the Go-jek application. Business partners who have registered with the Go-Food service will get Go-Food orders on the Go-Biz application and have the opportunity to increase sales by adding business areas to Gojek application users. With this Go-Food service, you can increase the number of orders by submitting photo banners that attract attention or impress customers, frequently updating photos of food menu offerings, and managing menu availability, operating hours and the status of opening or closing restaurants. Pempek Windy Sekumpul customers, who want to enjoy pempek at home, are unable or lazy to leave the house, can take advantage of the Go-Food facilities from the Go-jek service. Pempek ordered can be in the form of raw or cooked ready to eat. This service is usually used by residents of Martapura and its surroundings;

- Event based pempek marketing such as cheap markets, Banjar expo, cooking competitions, exhibitions organized by related agencies or institutions.

Maintaining good relationship with customers provide many benefits, including: improving customer relations and business value; keep customers from doing retransactions; get new customers by word of mouth marketing method; guarantee or guarantee to the customer is an investment in the future; get innovations from customers for long-term business plans. Understanding customers is important why and how to choose products, because it requires consumer profile information and market research.

Some things that need to be considered regarding Customer Relationship Management include:

- Improvement of Service to Customers. Keeping customers subscribed requires good service. A service culture must be applied to employees such as receiving calls, greeting and responding to customer complaints. Explore customer feedback as feedback from the service. Loyal customers need to be maintained, because they will help when in difficult times the business continues, and become a means of promotion to their colleagues or relatives. Customer complaints resolved in a professional manner, bad customer experience to be fixed. Customer complaints become valuable items to improve service and keep unsavory issues from spreading. Sometimes it is necessary to give gifts to loyal customers or new customers as a form of appreciation. Prizes can be in the form of discounts,

- Improved Product Quality Produced. If the service, marketing strategy, and place of business are good, but the product quality is poor, the customer will switch to another seller. Feedback or input from customers is responded to so that they can always upgrade products and products will always relate to consumer/market demands. Sales of substandard products are avoided. Manufacturers are very satisfied with their products before they are released to the market. The seller continuously reviews the supplier to ensure the quality of the goods, because the buyer makes transactions with the producer, not with the supplier. Never mind, get 2 or 3 suppliers. Which one has a comparative and competitive advantage in terms of price, quality, and service? Important competitors are also observed marketing strategy in addition to attention to buyers. The product must not be better than other manufacturers or at least the same quality. As Steve Jobs said: consumers don't want to know how much you worked hard to produce a product, but consumers only want to know the products you offer. So there is no tired dictionary to innovate and increase product quality. Pempek Windy Sekumpul in applying the above principles by responding quickly to customer complaints. Customer complaints that have occurred: the number of pempek ordered is less; the amount of change is less. The solution is to replace the less amount of pempek and return the less change. Not infrequently the owner himself comes directly to return the shortage of pempek and the change as a form of responsibility so that customers remain loyal and satisfied with the services provided. The owner also often delivers customer orders himself. The customer response is very appreciative; the award is delivered directly to the order by the owner 
directly. Owners can also find out directly what customers want.

The future business development strategy of Pempek Windy Sekumpul is formulated by conducting a SWOT analysis. The first step is to take an inventory of Strengths, Weaknesses, Opportunities and Threats (Ramadhani, 2020). Furthermore, weighting and rating are carried out to determine what quadrant is Pempek Windy Sekumpul from the analysis. Kudran will determine the positioning and business strategy of Pempek Windy Sekumpul.

The qualitative calculation of Pempek Windy's SWOT analysis is based on the following matrix:

Table 2 - Qualitative Approach to SWOT Analysis Pempek Windy Sekumpul

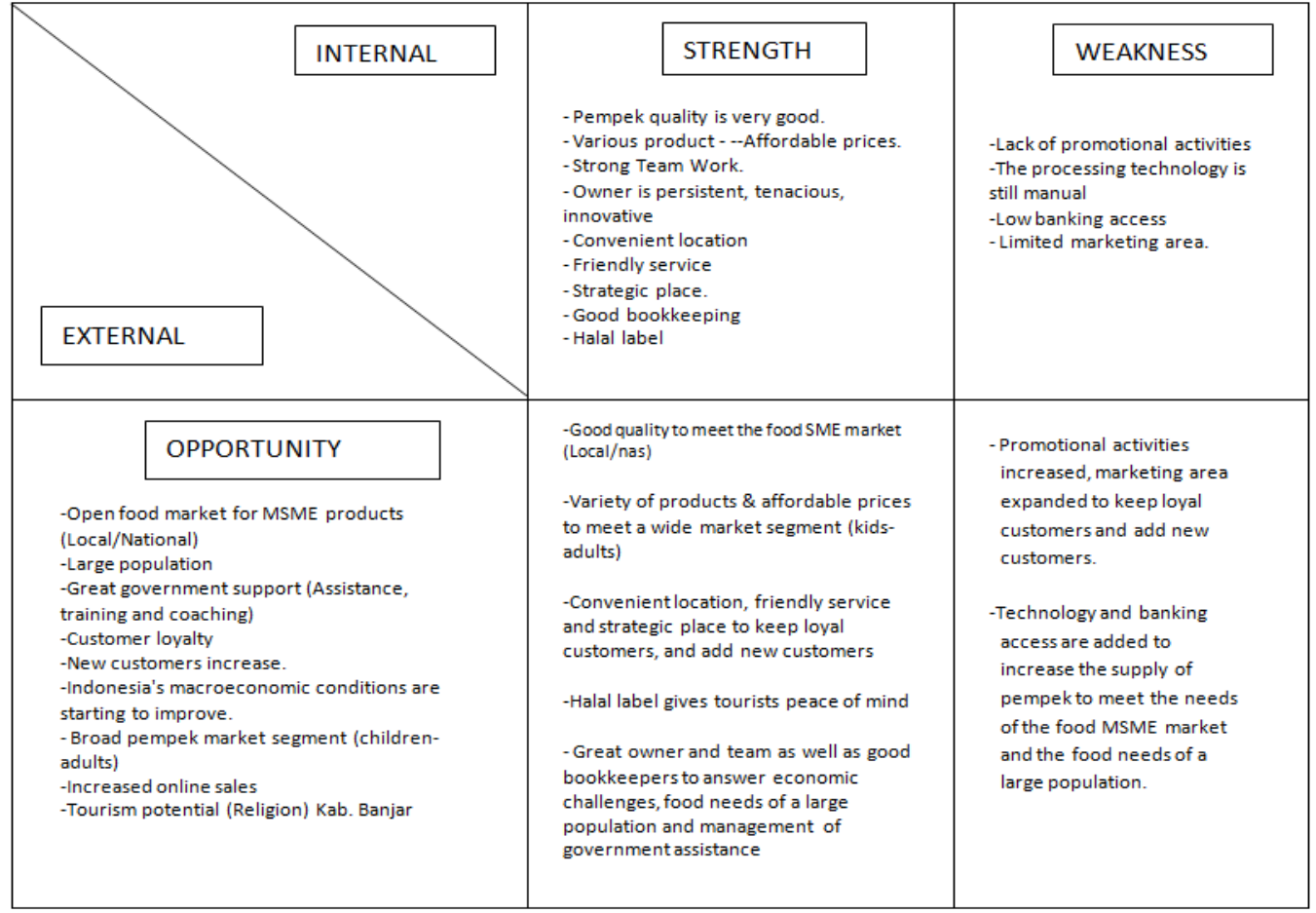

Source: Data Analysis, 2021.

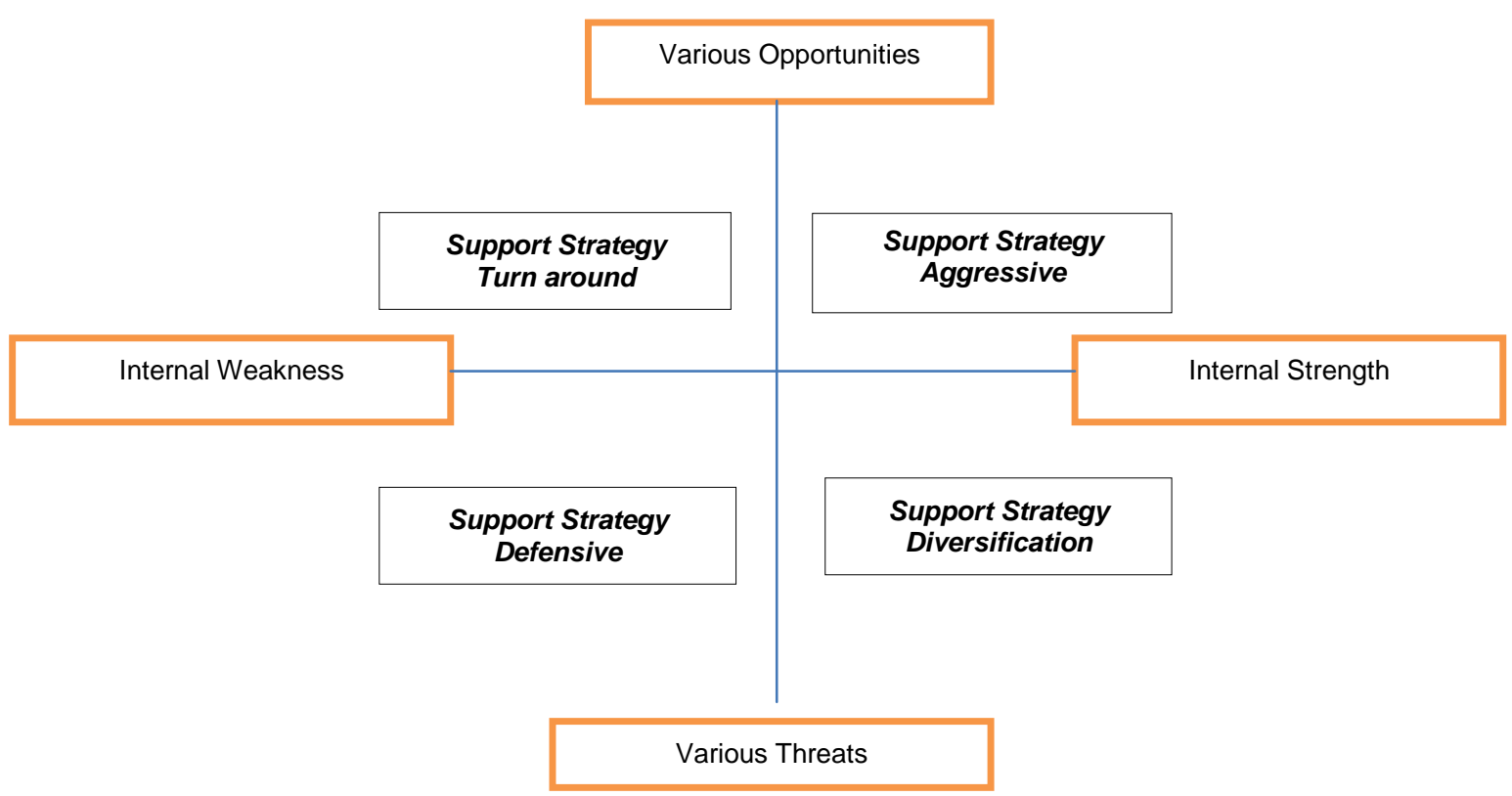

Figure 2 - Determination of quadrants in SWOT analysis 
Quadrant I (positive, positive). This position indicates a strong and potential organization. The strategic recommendation given is aggressive, meaning that the organization is in prime and stable condition so that it is very possible to continue to expand, increase growth and achieve maximum progress.

Quadrant II (positive, negative). This position signifies a strong organization but faces big challenges. The strategy recommendation given is Diversification, meaning that the organization is in a stable condition but faces a number of severe challenges, so it is estimated that the wheels of the organization will have difficulty continuing to spin if it only relies on the previous strategy. Therefore, organizations are advised to immediately increase their variety of tactical strategies.

Quadrant III (negative, positive). This position indicates an organization that is weak but very likely. The strategy recommendation given is Turn Around Strategy, meaning that the organization is advised to change its previous strategy. This is because the old strategy is feared to be difficult to capture existing opportunities and improve organizational performance.

Quadrant IV (negative, negative). This position signifies a weak organization facing major challenges. The strategic recommendation given is the Defensive Strategy, meaning that the internal conditions of the organization are in a dilemma choice. Therefore, the organization is advised to use a survival strategy, controlling internal performance so that it does not fall further. This strategy is maintained while continuing to improve ourselves(Safar, 2010).

The qualitative calculation of Pempek Windy's SWOT analysis is based on the following matrix:

Table 3 - Quantitative Calculation of SWOT Analysis Pempek Windy Sekumpul

\begin{tabular}{|c|c|c|c|c|}
\hline$n / n$ & Strategic Factor & Weight & Rating & Score \\
\hline \multirow[t]{10}{*}{ Strength } & - Pempek quality is very good. & 0.11 & 5 & 0.54 \\
\hline & - Various product. & 0.11 & 4 & 0.43 \\
\hline & - Affordable prices. & 0.11 & 5 & 0.54 \\
\hline & - Strong Team Work. & 0.09 & 4 & 0.36 \\
\hline & - Owner who is persistent, tenacious, innovative & 0.11 & 5 & 0.54 \\
\hline & - Convenient location & 0.09 & 4 & 0.36 \\
\hline & - Friendly service & 0.09 & 4 & 0.36 \\
\hline & - Strategic place. & 0.09 & 4 & 0.36 \\
\hline & - Good bookkeeping & 0.11 & 3.5 & 0.38 \\
\hline & - Have a Halal Certificate & 0.11 & 5 & 0.54 \\
\hline \multirow[t]{4}{*}{ Weakness } & - Lack of promotional activities & 0.32 & 2 & 0.63 \\
\hline & - Manual processing technology & 0.21 & 2 & 0.42 \\
\hline & - Low banking access & 0.21 & 1.5 & 0.32 \\
\hline & - Limited marketing area. & 0.26 & 2 & 0.53 \\
\hline \multirow[t]{8}{*}{ Opportunity } & - Open food market for MSME products (Local/National) & 0.14 & 4 & 0.54 \\
\hline & - Large population & 0.11 & 4 & 0.43 \\
\hline & - Great government support (Assistance, training and coaching) & 0.11 & 3.5 & 0.38 \\
\hline & - Customer loyalty & 0.16 & 4.5 & 0.73 \\
\hline & -New customers increase. & 0.11 & 3 & 0.32 \\
\hline & - Indonesia's macroeconomic conditions are starting to improve. & 0.08 & 2.5 & 0.20 \\
\hline & - Broad pempek market segment (children-adults) & 0.16 & 4.5 & 0.73 \\
\hline & - Increased online sales & 0.14 & 3.5 & 0.47 \\
\hline \multirow[t]{3}{*}{ Threats } & - Products are easy to imitate & 0.38 & 1.5 & 0.56 \\
\hline & - Many competitors / sellers of similar products & 0.375 & 1 & 0.38 \\
\hline & - Scarcity of Raw Materials & 0.25 & 2 & 0.50 \\
\hline
\end{tabular}

Source: Data Analysis, 2021.

Based on the quantitative calculation of the SWOT analysis, Pempek Windy Sekumpul is in Quadrant I with coordinates $(2.48 ; 2.37)$. This position indicates that Pempek Windy Sekumpul is strong and has the opportunity. The recommended strategy given is aggressive, meaning that Pempek Windy Sekumpul is in prime and stable condition so that it is very possible to continue to expand, increase growth and achieve maximum progress. 


\section{CONCLUSION}

Based on the results of the study, it can be concluded as follows: There is no significant difference in the offer of Pempek Windy Sekumpul before and during the Cocid-19 pandemic. This means that the Covid-19 pandemic does not have a significant impact on the Pempek Windy Sekumpul Offers. The initial strategy to survive Pempek Windy Sekumpul during the Covid-19 Pandemic was very affordable pempek prices, strategic place, maintain the availability of raw materials for production, price, solid team work, strong owner character, diverse product marketing system, and customer relationship management to establish good relationships with customers. The business development strategy of Pempek Windy Sekumpul Martapura in the future is an aggressive strategy, meaning that Pempek Windy Sekumpul is in prime and stable condition, so it is highly recommended to continue to expand, diversify products to enlarge business growth and achieve maximum progress.

Based on the conclusions above, it can be suggested that:

- Zero Waste Concept needs to be applied in making this pempek, bones, head and entrails can be utilized. Fish bones and heads can be reprocessed as raw material for pempek, while the stomach contents are used as a feed mixture for ducks. Improved processing technology by using a mixer, bone and meat separator, etc. so that production is more efficient and competitive and anticipates when there is a spike in orders for pempek at certain events such as birthdays, official government events, Eid, exhibitions, events on campus etc;

- The end of the Covid-19 pandemic is still unclear, so steps are needed: maintain health protocols, maintain product safety and customer health; adaptive to the shopping trends of customers who tend to shop online. Customers want quality products that are kept clean and safe without having to leave the house;

- The aggressive strategy requires the readiness of capital, location, infrastructure, market access, human resources, etc., to expand business development and increase the offer of Pempek Windy Sekumpul.

\section{ACKNOWLEDGEMENTS}

Authors would like to thank Pempek Windy Sekumpul for provided time and place of this research.

\section{REFERENCES}

1. Akhmad. 2014. Ekonomi Mikro-Teori dan Aplikasi di Dunia Usaha. C.V Andi Offset (Penerbit Andi).

2. Bappeda Gunung Kidul. 2020. Usaha-Usaha yang tetap bertahan ditengah pandemi covid-19 http://bappeda.gunungkidulkab.go.id/2020/05/usaha-usaha-yang-tetapbertahan-ditengah-pandemi-covid-19/. Diakses tanggal 6 Oktober 2021.

3. Doolin et.al. 2005. "Perceived Risk, The Internet Shopping Experience and Online Purchasing Behavior: A New Zealand Perspective". Journal of Global Information Management. Vol 13, No 2.

4. Fajri, M., dan Dasir. 2017. Studi tenggang waktu penggunaan daging ikan gabus pada pembuatan pempek lenjer. Edible. 6(1): 20-26.

5. Febrantara. 2020. Bagaimana Penanganan UKM di Berbagai Negara Saat Ada Pandemi Covid-19? DDTC Fiscal Research.Retrieved from https://drive.google.com/drive/folders/1MY31IOC3gWq-EgzNkuJzqJnB9PV6qA2D.

6. Gilarso, T., 2003. Pengantar IImu Ekonomi Mikro, edisi revisi.Yogyakarta: Penerbit kanisius.

7. Hanafie. 2010. Pengantar Ekonomi Pertanian. C.V Andi Offset (Penerbit Andi) Hal (171176).

8. Hardilawati. 2020. Strategi Bertahan UMKM di Tengah Pandemi Covid-19. Jurnal Akuntansi \& Ekonomika Vol. 10 No. 1 http://ejurnal.umri.ac.id/index.php/jae. 
9. Hidayat, Taufik. 2008. Panduan Membuat Toko Online dengan OSCommerce, Jakarta: Mediakita.

10. Hoesni. 2007. Seri Quick Cooking: Pempek dan Variasinya. Gramedia Pustaka Utama.

11. Kameta. 2010. Analisis Kelayakan Ekonomi Dan Optimasi Formulasi Pempek Lenjer Skala Industri. *Jurusan Sosial Ekonomi Pertanian STIPER Sriwigama Palembang. Jurnal Pembangunan Manusia Vol.4 No.12. https://docplayer.info/41795206-Analisiskelayakan-ekonomi-dan-optimasi-formulasi-pempek-lenjer-skala-industri.html.

12. Karneta, R., Rejo, A., Priyanto, G., and Pambayun, R. 2013. Difusivitas panas dan umur simpan pempek lenjer. Jurnal Keteknikan Pertanian, 27 (2): 131-141.

13. Laudon. 2008. Sistem Informasi Manajemen Mengelola Perusahaan Digital: Buku 2. Salemba Empat.

14. Meier, Andreas \& Stormer, Henrik. 2009. eBusiness \& eCommerce: Managing the Digital Value Chain. Springer Berlin Heidelberg.

15. Permatasari . 2021. Kebijakan Covid-19 dari PSBB hingga PPKM Empat Level. Kompas Pedia. https://kompaspedia.kompas.id/baca/infografik/kronologi/kebijakan-covid-19-daripsbb-hingga-ppkm-empat-level. Diakses Tanggal 13 September 2021.

16. Pieniak, Z., W. Verbeke, F. Vanhonacker, L. Guerrero, and M. Hersleth. 2009. Association between traditional food consumption and motives for food choice in six European countries. Appetite Journal. 53: 101-108.

17. Prihatna, Henky. 2005. Kiat praktis menjadi web master professional. Jakarta.: PT.Elexmedia Komputindo.

18. Ramadhani. 2020. Mengenal Analisa Swot dengan Contoh Penerapannya. https://www.akseleran.co.id/blog/swot-adalah/. Diakses Tanggal 31 Agustus 2021.

19. Raharjo. 2014. Panduan Lengkap cara melakukan Uji Wilcoxon dengan SPSS. https://www.spssindonesia.com/2017/04/cara-uji-wilcoxon-spss.html.

20. Riadi. 2020. Analisis SWOT (Pengertian, Tujuan, Aspek, Kuadran dan Matriks). KajianPustaka.com. https://www.kajianpustaka.com/2020/09/analisis-SWOT.html.

21. Safar. 2010. Statistic of live. https://exponensial.wordpress.com.

22. Suryaningrum, T.D, ljah Muljanah. (2009). Prospek Pengembangan Usaha Pengolahan Pempek Palembang. Squalen Vol. 4 No. 1, Mei 2009.

23. Siregar, Syofian. 2013. Metode Penelitian Kuantitatif. Jakarta: PT Fajar Interpratama Mandiri.

24. Sugito dan A. Hayati. 2006. Penambahan daging ikan gabus (Ophicepallus strianus BLKR) dan aplikasi pembekuan pada pembuatan pempek gluten. Jurnal Ilmu Pertanian Indonesia. 8(2): 147-151.

25. Trimawartinah. 2020. Buku Ajar Statistik Non Parametrik. Edisi Perdana. Uhamka. 